\title{
SISTEM INFORMASI DOKUMEN PENDUKUNG UJIAN AKHIR SEMESTER
}

\author{
Muhammad Najibulloh Muzaki', M. Dewi Manikta Puspitasari ${ }^{2)}$, dan Rini Indriati ${ }^{3)}$ \\ ${ }^{1,2,3)}$ Fakultas Teknik dan Universitas Nusantara PGRI Kediri

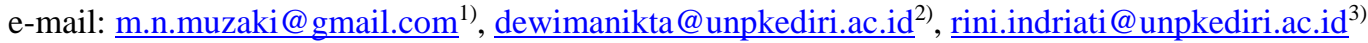

\begin{abstract}
Abstrak : Pelaksanaan ujian akhir semester merupakan agenda rutin dalam setiap semester bagi Program Studi Sistem Informasi Universitas Nusantara PGRI Kediri. Dalam pelaksanaan ujian akhir semester, beberapa dokumen pendukungnya adalah jadwal ujian, berita acara ujian dan daftar hadir peserta ujian.

Dalam dokumen berita acara ujian dan daftar hadir peserta ujian, beberapa isian harus ditulis tangan oleh pengawas. Beberapa isian tersebut antara lain data hari, tanggal, jam ujian, ruang ujian, nama mata kuliah, pengampu, kelas dan nama pengawas. Masing-masing dari dokumen tersebut dibuat dalam 2 rangkap, sehingga proses pengisian tersebut dapat menyita waktu pengawas ketika melakukan tugas pengawasan. Apabila dicermati, beberapa isian tersebut sebenarnya telah ada di dalam jadwal ujian, tinggal bagaimana caranya agar data yang ada dalam jadwal dapat diitegrasikan untuk melengkapi isian-isian tersebut. Permasalahan tersebut ada adalah karena belum adanya sistem maupun basis data yang menjadi landasan dalam pembuatan dokumen-dokumen tersebut.

Penelitian ini bertujuan untuk memberikan solusi serta kontribusi dengan membangun suatu sistem informasi yang membantu pembuatan dokumen pendukung ujian akhir semester bagi Program Studi Sistem Informasi Universitas Nusantara PGRI Kediri. Dokumen yang akan dihasilkan adalah jadwal ujian, berita acara ujian dan daftar hadir peserta ujian. Proses Pembangunan sistem menggunakan bahasa pemrograman PHP serta dukungan basis data MySQL.

Sebagai hasil dari penelitian dilakukan uji perbandingan waktu pengisian lembar berita acara ujian dan lembar daftar hadir peserta ujian yang selama ini digunakan dibandingkan dengan lembar yang dihasilkan dari sistem. Hasil uji perbandingan menunjukkan bahwa dokumen yang dihasilkan oleh Sistem Informasi Dokumen Pendukung Ujian Akhir Semester dapat menghemat waktu pengisian menjadi lebih cepat dengan selisih rata-rata waktu pengisian sebesar 97.85 detik untuk lembar berita acara ujian dan 43.7 detik lembar daftar hadir peserta ujian.
\end{abstract}

Kata Kunci_sistem Informasi, sistem pembuatan dokumen, dokumen pendukung ujian akhir semester

Abstract : The final semester examination is a routine agenda for each semester for the Program Studi Sistem Informasi Universitas Nusantara PGRI Kediri. In the implementation of the final semester exams, some of the supporting documents are the exam schedule, minutes of the exam and the list of attendees of the exam.

In the minutes of the exam and the attendance list, some entries must be written by the supervisor. Some of the fields include data on day, date, exam time, exam room, course name, lecturer, class and supervisor's name. Each of these documents is made in 2 copies, so that the filling process can take up the time of the supervisor when carrying out supervisory duties. When examined, some of the entries are actually already in the exam schedule, just how to make the data contained in the schedule can be integrated to complete the fields. This problem exists because there is no system or database that is the basis for making these documents. This study aims to provide solutions and contribute by building an information system that helps produce end-semester exam supporting documents for the Information Systems Study Program at the Nusantara University PGRI Kediri. The documents that will be produced are the exam schedule, minutes of the exam and the list of attendees of the exam. The system development process uses the PHP programming language and MYSQL database support.

As a result of the study a comparison test was carried out when filling out the minutes of the exam and the attendance sheet of the examinees that had been used compared to the sheets produced from the system. The results of the comparative test show that the documents produced by the Information System for Supporting Final Examination Semester Documents can save filling time faster by an average difference in filling time of 97.85 seconds for the minutes of the exam and 43.7 seconds for the list of attendees of the exam.

Keywords - Information system, document making system, end of semester examination supporting documents

$\mathrm{P}$

elaksanaan ujian akhir semester (UAS) merupakan rutinitas bagi Program Studi Sistem Informasi Universitas Nusantara PGRI Kediri. Persiapan yang tentunya juga rutin dilakukan adalah terkait dengan

DOI: https://doi.org/10.35457/antivirus.v13i2.848 
dokumen-dokumen yang mendukung terlaksananya ujian akhir semester (UAS). Dokumen tersebut beberapa diantaranya adalah jadwal ujian, daftar hadir mahasiswa dan berita acara ujian.

Berdasarkan pengamatan yang dilakukan, proses penyiapan dokumen-dokumen tersebut dilakukan secara terpisah, sehingga belum ada sinkronisasi data antar dokumen-dokumen tersebut. Sebagai contoh, data hari, tanggal, jam, ruang, mata kuliah dan nama pengawas telah jelas tercantum dalam jadwal ujian, namun pada dokumen lainnya yaitu berita acara dan daftar hadir mahasiswa data tersebut masih harus diisi secara manual dengan ditulis tangan oleh pengawas.

Bentuk solusi yang saat ini sedang digunakan adalah dengan membuat dokumen dalam bentuk formulir kosong dan untuk pengisian dilakukan dengan ditulis tangan. Hal tersebut dapat menyingkat waktu penyiapan dokumen, karena tidak perlu memikirkan dokumen yang berbeda untuk kelas maupun mata kuliah yang berbeda. Pada sisi yang lain, hal tersebut memunculkan masalah baru yaitu memerlukan waktu pengisian oleh pengawas yang lebih lama karena harus mengisi satu persatu isian yang ada pada beberapa jenis dokumen dan masing-masing dokumen tersebut terdiri dari dua rangkap untuk satu sesi atau satu mata kuliah. Pada saat yang sama, pengawas juga harus melakukan tugas pengawasan terhadap peserta ujian.

Penelitian ini bertujuan untuk memberikan solusi bagi Program Studi Sistem Informasi Universitas Nusantara PGRI Kediri dengan membangun suatu sistem informasi yang membantu pembuatan dokumen pendukung UAS, seperti jadwal ujian, berita acara ujian dan daftar hadir peserta ujian, dengan dukungan basis data sehingga proses pembuatan dokumen tersebut dilakukan secara sistematis dan otomatis melalui sistem dan dokumen yang dihasilkan dapat mempersingkat waktu pengisian dokumen oleh pengawas.

\section{LANDASAN TEORI}

Sistem informasi dokumen memiliki beberapa fokus penelitian, salah satunya adalah sistem peringkas dokumen menggunakan algoritma Latent Semantic Analysis (LSA) yang bertujuan untuk meringkas dokumen secara otomatis sebagai masukan untuk proses selanjutnya yaitu clustering dokumen [1].

Pada penelitian yang lain, sistem dan metode telah di kembangkan, untuk kolaborasi dokumen antara penulis yang mengelola menggunakan Document Management System (DMS) dengan satu atau lebih penulis yang dapat berkontribusi didalamnya [2].

Masih terkait dengan Document Management System (DMS) yaitu penelitian yang bertujuan untuk mempermudah proses pengelolaan seperti pencarian dan pengiriman dokumen-dokumen standart operational procedure dengan menggunakan Document Management System (DMS) [3].

Implementasi Document Management System (DMS) selanjutnya adalah penelitian terkait dengan pengelolaan dokumen pada bagian SDM yang bertujun untuk mempercepat proses kerja dan membantu serta memudahkan bagian SDM dalam proses penyimpanan, pencarian dan dokumen [4].

Penelitian selanjutnya adalah sistem informasi pengaksesan dan pengiriman dokumen rancangan dalam proses pencetakan PCB. Tujuan utama dari penelitian ini adalah selain untuk mereduksi penggunaan kertas dalam proses produksi, juga untuk memudahkan dalam proses pengiriman. dokumen karena dapat dilakukan via on-line [5].

Pada penelitian lain telah mengimplementasikan sistem pengelolaan arsip dokumen pada Unit Pelayanan Pajak dengan beberapa fitur didalamnya seperti penginputan data penyimpanan data dan juga pencarian data pajak [6].

\section{METODE PENELITIAN}

Pada penelitian ini memiliki beberapa tahapan seperti ditunjukkan pada gambar 1. Tahap awal adalah Persiapan penelitian dilanjutkan dengan proses penelitian yang merupakan tahapan inti dalam penelitian. Tahap ketiga adaah pembuatan laporan dan tahap keempat adalah realisasi luaran. 


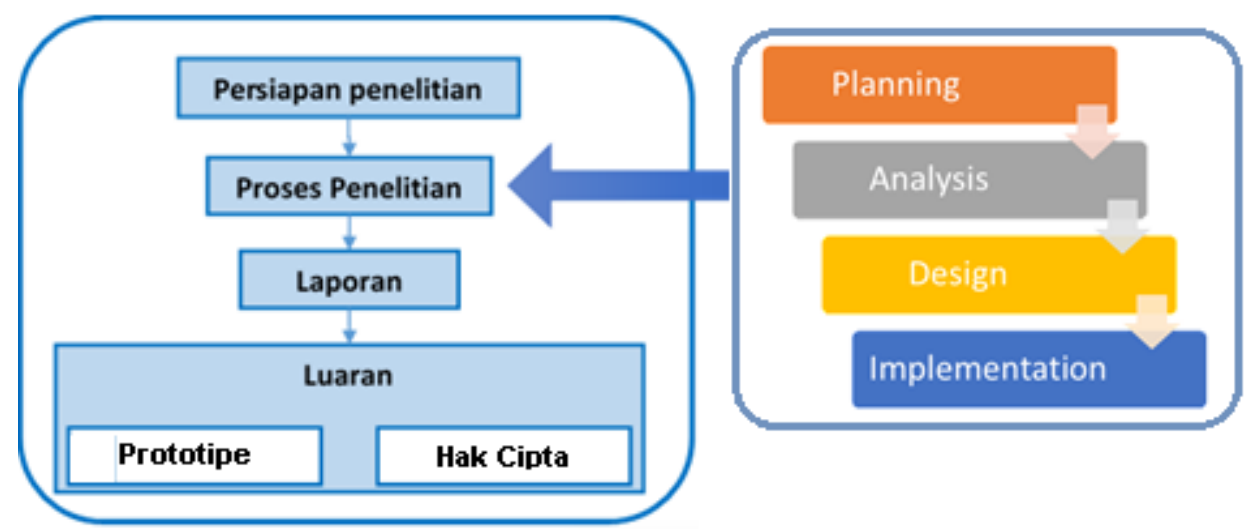

Gambar 1 Bagan Penelitian

Proses penelitian menggunakan konsep System Development Life Cycle (SDLC) dengan metode yang digunakan adalah metode Waterfall dengan tahapan :

a. Tahap perencanaan (Planning) dengan melakukan identifikasi permasalahan, batasan dan tujuan dari sistem informasi dokumen pendukung ujian akhir semester pada Program Studi Sistem Informasi Universitas Nusantara PGRI Kediri. Dokumen pendukung ujian akhir semester tersebut meliputi jadwal ujian, daftar hadir pengawas, daftar hadir mahasiswa dan berita acara.

b. Tahap analisis (Analysis) dilakukan dengan menganalisis siapa yang akan menggunakan sistem, apa yang akan dilakukan oleh sistem, menginvestigasi proses pembuatan dokumen pendukung ujian akhir semester, mengidentifikasi perbaikan apa saja yang bisa dilakukan dan membuat konsep baru yaitu sistem informasi dokumen pendukung ujian akhir semester.

c. Tahapan desain (Design) dilakukan dengan mendesain perangkat lunak sistem informasi dokumen pendukung ujian akhir semester. Desain yang dilakukan meliputi desain proses, desain data dan desain tampilan menggunakan Data Flow Diagram, Entitiy Relationship Diagram dan desain interface.

Hasil implementasi mengacu pada rancangan yang telah dibuat. Rancangan database ditunjukkan pada Gambar 2. Istilah database memiliki arti sebagai berikut: Secara umum database berarti koleksi data yang saling terkait [7]. Secara praktis, basis data dapat dianggap sebagai suatu penyusunan data yang terstruktur yang disimpan dalam media pengingat ( hard disk ) yang tujuannya adalah agar data tersebut dapat diakses dengan mudah dan cepat.

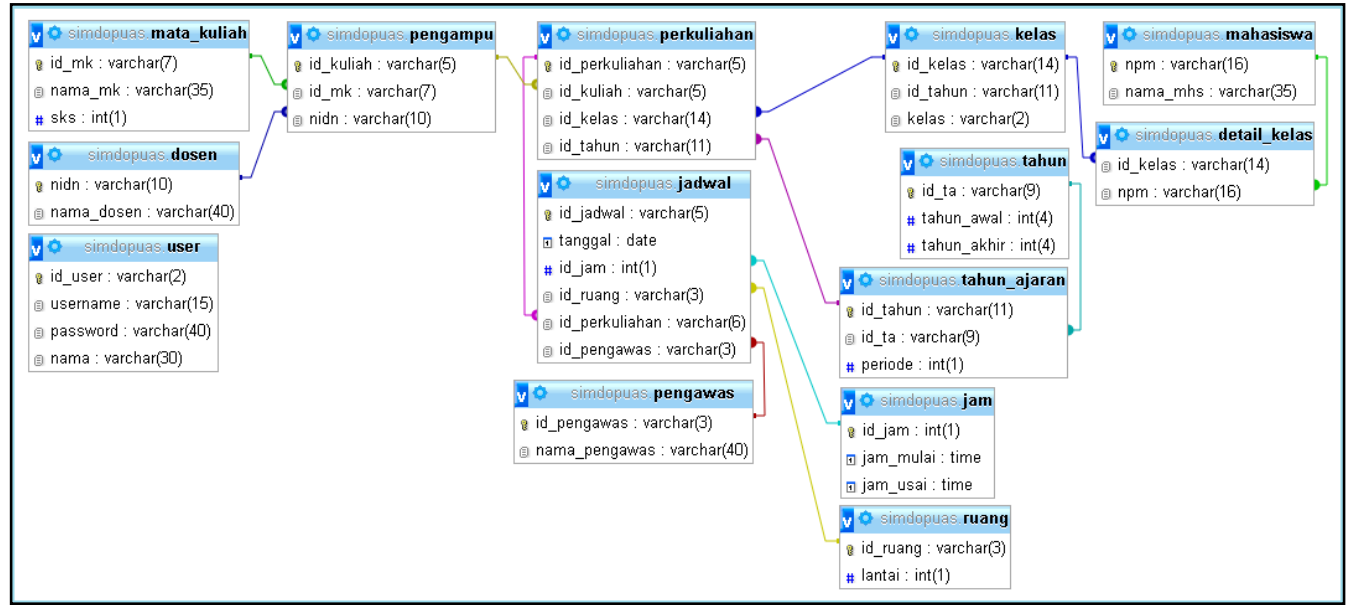

Gambar 2. Rancangan database

Rancangan diagram aliran data secara umum dalam sistem ditunjukkan pada Gambar 3. Penjabaran diagram aliran data secara detail ditunjukkan pada Gambar 4 dan lebih detail ditunjukkan oleh Gambar 5. Entitas utama adalah petugas yang menjalankan seluruh proses yang ada dalam Sistem Informasi Dokumen 
Pendukung Ujian Akhir Semester (SiDOPUAS). Petugas dapat melakukan manajemen data dengan melakukan input data, update data, delete data dan read data. Data tersebut adalah Data Tahun, Data Tahun Ajaran, Data Dosen, Data Mata Kuliah, Data Pengampu, Data Kelas, Data Perkuliahan, Data Mahasiswa, Data Absensi Kelas, Data Ruang, Data Jam Ujian dan Data Jadwal. Petugas juga dapat melakukan pencetakan dokumen jadwal, Berita acara ujian dan daftar hadir peserta ujian.

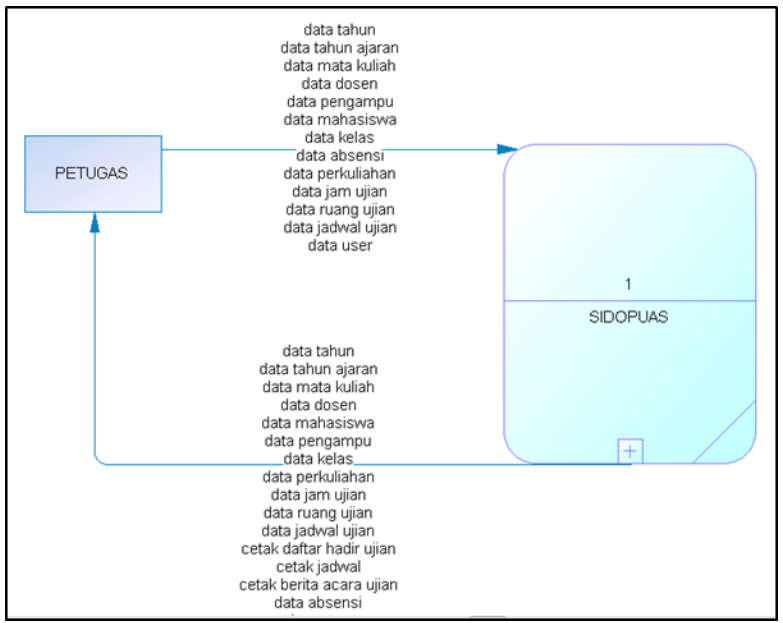

Gambar 3. DFD Level 0

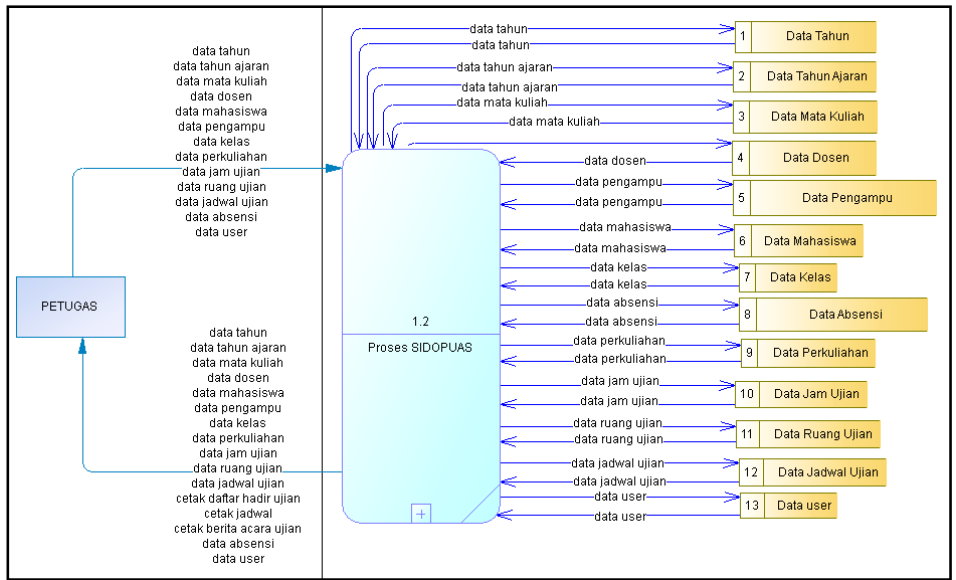

Gambar 4. DFD Level 1

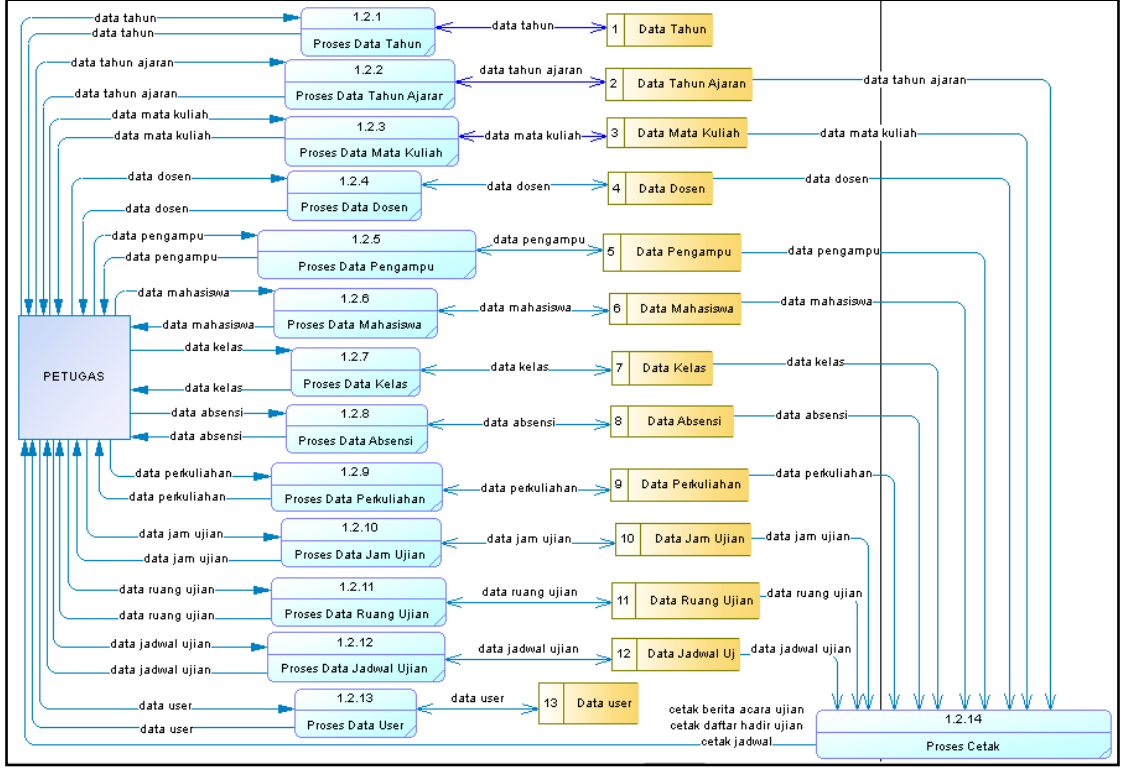


d.Tahapan implementasi (Implementation) dilakukan dengan mengaplikasikan desain ke dalam bahasa pemrograman. Bahasa pemrograman yang digunakan, yaitu: PHP dan MySQL. Langkah selanjutnya adalah melakukan pengujian dan penerapan atau instalasi sistem sistem informasi dokumen pendukung ujian akhir semester.

\section{HASIL DAN PEMBAHASAN}

Pembangunan sistem informasi membutuhkan data, biaya pengadaan, pengolahan dan penyimpanan dan sebagainya. Sebuah sistem informasi ditujukan untuk mempermudah kinerja, mengurangi biaya dan mempercepat pengolahan data menjadi informasi bagi organisasi. Hal tersebut selaras dengan konsep sinergi, dimana Output yang dihasilkan organisasi diharapkan lebih besar dari output pada masing-masing bagian [8].

Suatu sistem didalam suatu organisasi yang merupakan kombinasi dari orang-orang fasilitas, teknologi, media, prosedur-prosedur dan pengendalian yang ditujukan untuk mendapatkan jalur komunikasi penting memproses tipe transaksi rutin tertentu, memberi sinyal kepada manajemen dan yang lainnya terhadap kejadian-kejadian intenal dan eksternal yang penting dan menyediakan suatu dasar informasi untuk pengambilan keputusan yang cerdik [9].

\section{A. Implementasi sistem}

Tampilan secara keseluruhan dari hasil implementasi sistem yang telah dibangun terdapat pada Gambar 6 . Pada halaman utama terdapat menu yang terletak pada sebelah kiri halaman. Menu tersebut digunakan untuk mengakses halaman-halaman manajemen data. Halaman manajemen data digunakan untuk memproses data yang dibutuhkan untuk pembuatan dokumen pendukung ujian akhir semester. Pada tabel 1 memuat tentang data yang digunakan, serta nama halaman untuk memanajemen data tersebut.

TABEL I

DATA DAN HaLAMAN MANAJEMEN DATA

\begin{tabular}{lll}
\hline \hline Nomor & \multicolumn{1}{c}{ Data } & \multicolumn{1}{c}{ Halaman Manajemen Data } \\
\hline 1 & Data Tahun & Halaman Data Tahun \\
2 & Data Tahun Ajaran & Halaman Data Tahun Ajaran \\
3 & Data Dosen & Halaman Data Dosen \\
4 & Data Mata Kuliah & Halaman Data Mata Kuliah \\
5 & Data Pengampu & Halaman Data Pengampu \\
6 & Data Kelas & Halaman Data Kelas \\
7 & Data Perkuliahan & Halaman Data Perkuliahan \\
8 & Data Mahasiswa & Halaman Data Mahasiswa \\
9 & Data Absensi Kelas & Halaman Data Absensi Kelas \\
10 & Data Ruang & Halaman Data Ruang \\
11 & Data Jam Ujian & Halaman Data Jam Ujian \\
12 & Data Jadwal & Halaman Data Jadwal \\
\hline \hline
\end{tabular}


ANTIVIRUS: Jurnal Ilmiah Teknik Informatika (p - ISSN: 1978 - 5232; e - ISSN: 2527 - 337X)

Vol. 13 No. 2 November 2019, pp. $120-128$

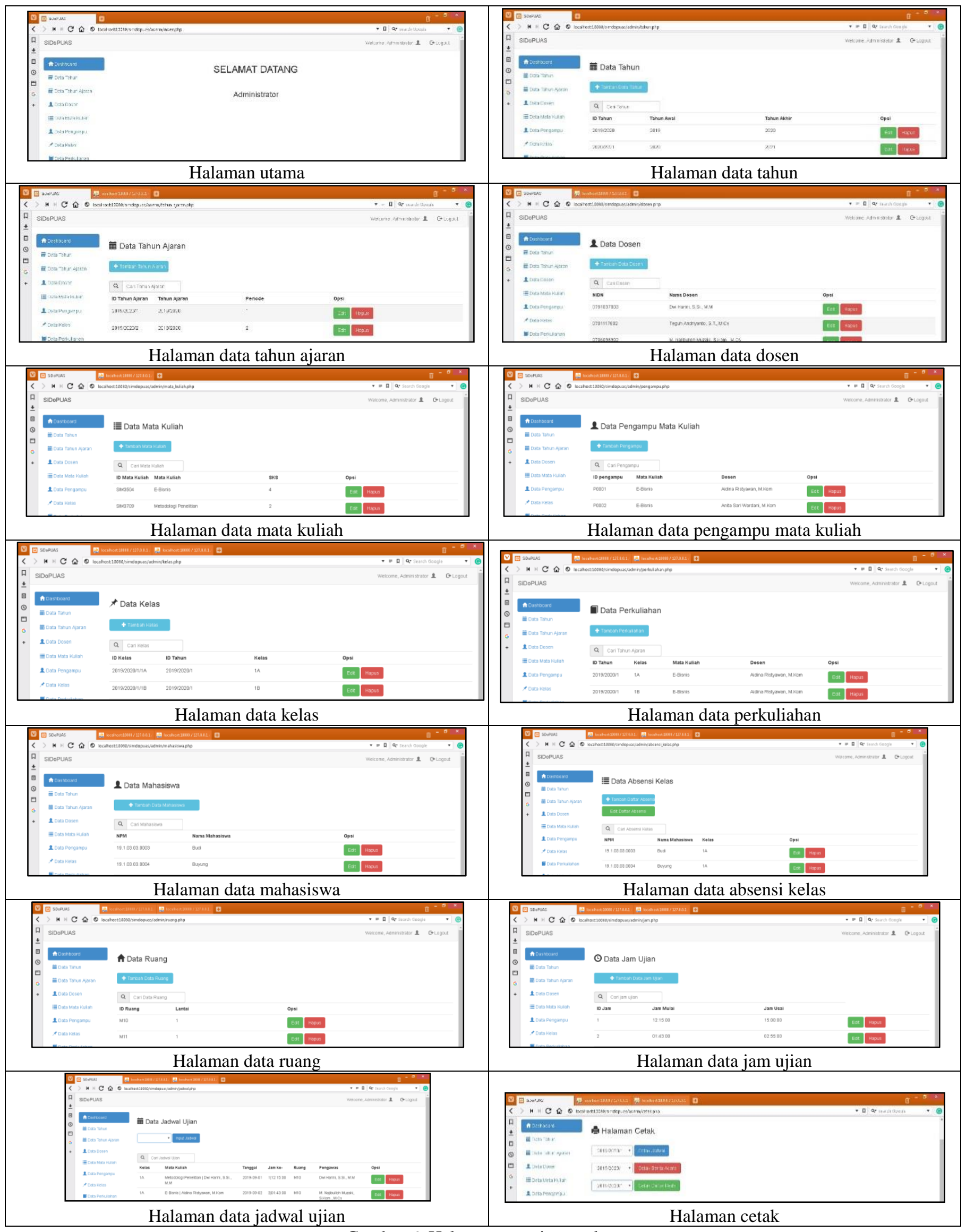

Gambar 6. Halaman manajemen data 
Pada Gambar 7 menunjukkan hasil tampilan untuk lembar jadwal ujian. Informasi yang dimuat oleh jadwal dibuat dari data yang telah tersimpan dalam database. Pengguna dapat menyimpan halaman tersebut dalam bentuk file berekstensi .pdf atau pengguna dapat juga langsung mencetak halaman tersebut melalui menu print yang terletak di pojok kanan atas.

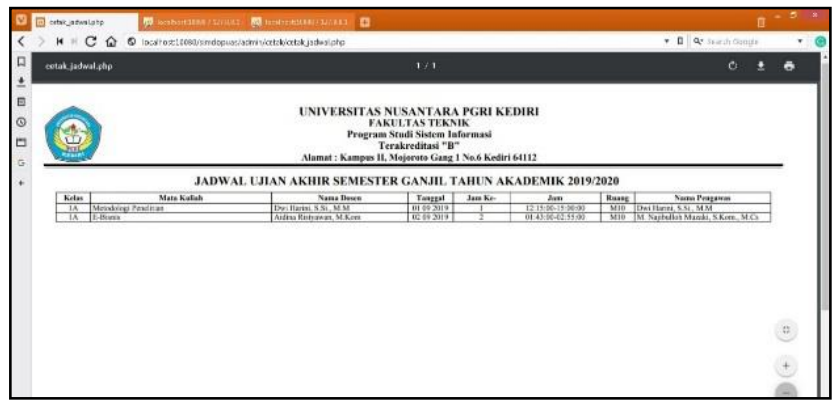

Gambar 7 Tampilan hasil cetak jadwal

Pada Gambar 8 dan gambar 9 menunjukkan hasil tampilan untuk lembar berita acara dan lembar daftar hadir. Lembar-lembar tersebut seluruhnya dibuat pada halaman cetak. Format dari berita acara dan daftar hadir dibuat sama persis dengan format manualnya, yang membedakan adalah beberapa isian yang awalnya harus ditulis tangan, oleh sistem sudah diisi dengan data,sehingga nantinya pengawas tidak perlu lagi mengisi isian terebut. Pengguna dapat mengunduh halaman tersebut dalam bentuk file berekstensi .pdf atau pengguna juga dapat mencetak menggunakan menu print.

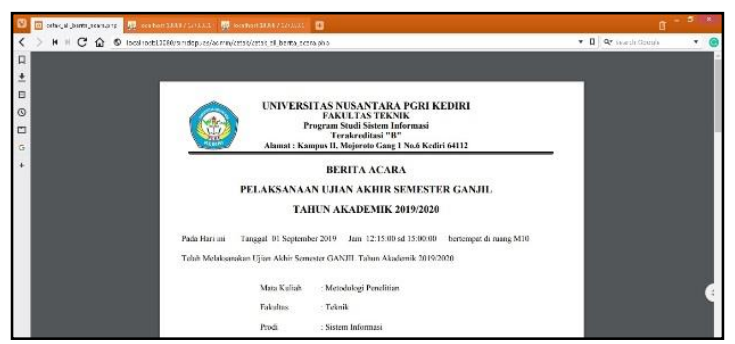

Gambar 8 Dokumen cetak berita acara

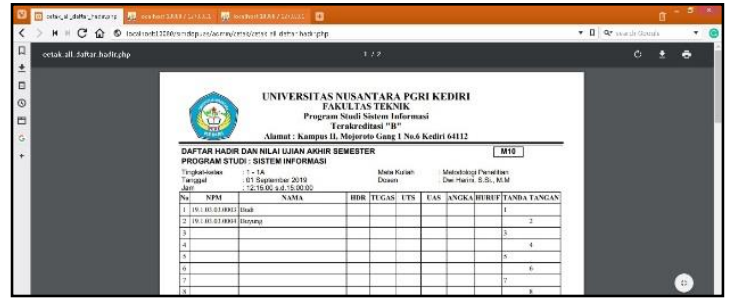

Gambar 9 Dokumen cetak daftar hadir

\section{B. Uji perbandingan waktu pengisian}

Tahap akhir setelah sistem selesai diimplementasikan adalah menguji perbandingan catatan waktu yang digunakan untuk mengisi lembar berita acara dan lembar daftar hadir pada proses manual dibandingkan dengan lembar yang dihasilkan oleh sistem. Hasil pengujian pada gambar 10 menunjukkan bahwa pengisian lembar berita acara ujian pada lembar manual membutuhkan waktu diatas 1 menit, sementara pengisian lembar yang dihasilkan oleh sistem memiliki catatan waktu pengisian dibawah 0.5 menit. Pada gambar 11 menunjukkan bahwa pengisian lembar daftar hadir ujian pada lembar manual membutuhkan waktu diatas 30 detik, sementara pengisian lembar yang dihasilkan oleh sistem tidak perlu lagi dilakukan sehingga catatan waktu pengisiannya adalah 0 detik. 
ANTIVIRUS: Jurnal Ilmiah Teknik Informatika (p - ISSN: 1978 - 5232; e - ISSN: 2527 - 337X)

Vol. 13 No. 2 November 2019, pp. $120-128$

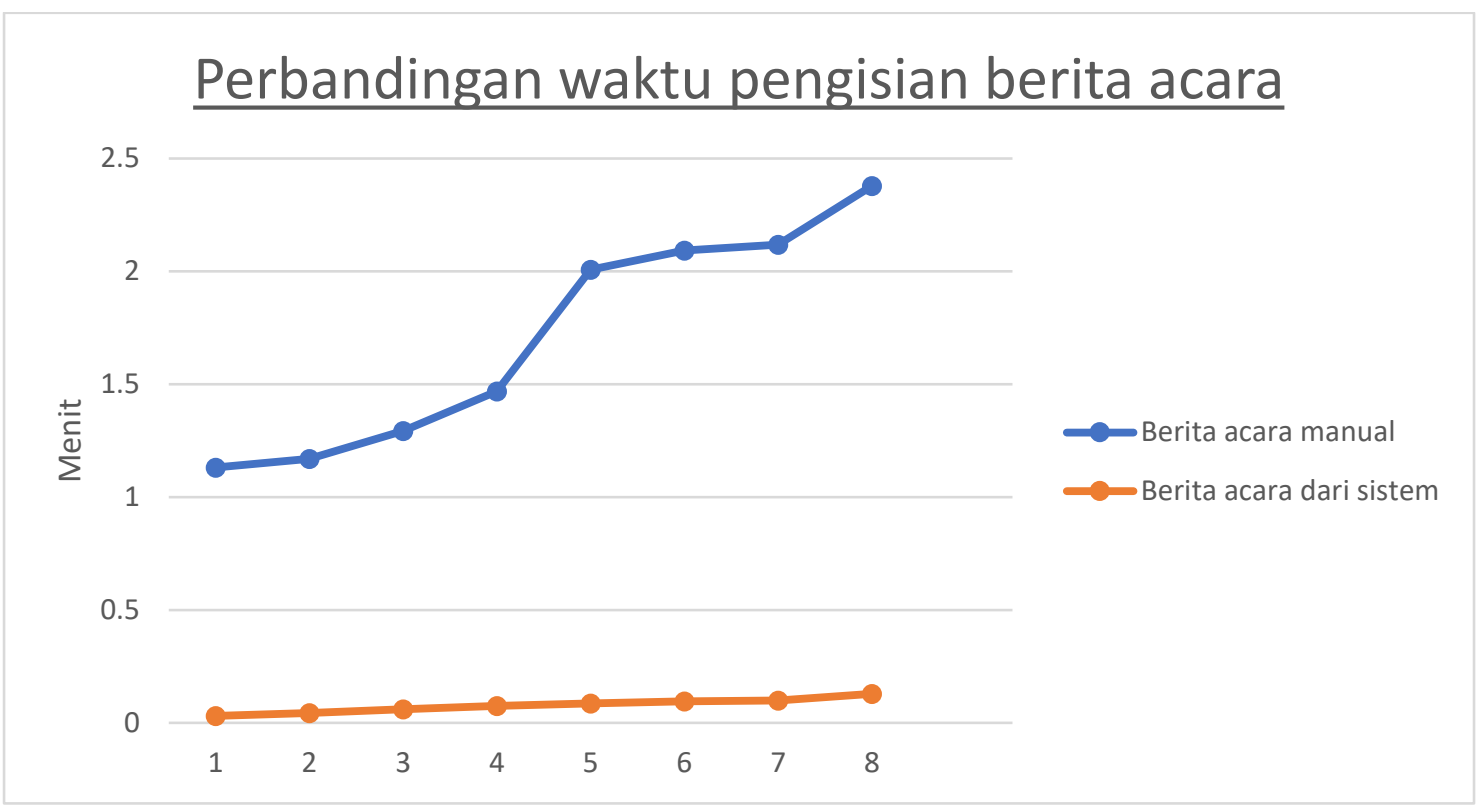

Gambar 10 Perbandingan waktu pengisian berita acara

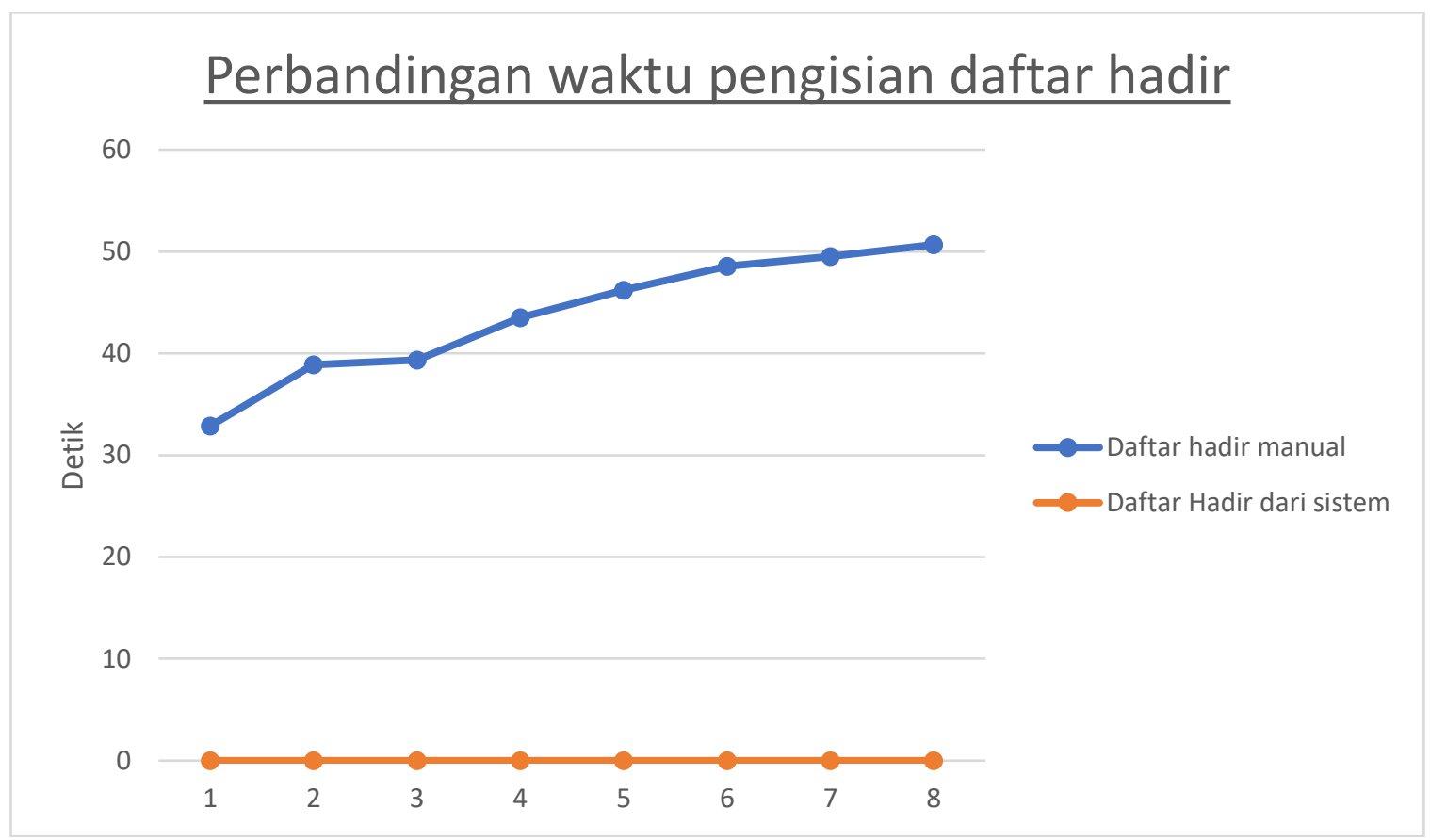

Gambar 11 Perbandingan waktu pengisian daftar hadir

TABEL 2

RATA-RATA WAKTU PENGISIAN

\begin{tabular}{lccc}
\hline \hline Nama lembar & Lembar manual & Lembar dari sistem & Selisih \\
\hline Berita acara & 102.45 detik & $\mathbf{4 . 6}$ detik & 97.85 detik \\
Daftar hadir & 43.7 detik & 0 detik & 43.7 detik \\
\hline \hline
\end{tabular}

Hasil akhir dari uji perbandingan ditunjukkan pada tabel 2 dengan waktu pengisian diperoleh waktu rata-rata 102.45 detik untuk pengisian lembar berita acara manual dan 43.7 detik untuk pengisian lembar daftar hadir manual. Sedangkan lembar dari sistem membutuhkan rata-rata waktu pengisian 4.6 detik untuk 
pengisian lembar berita acara dan 0 detik untuk pengisian lembar daftar hadir. Selisih waktu pengisian adalah 97.85 detik untuk pengisian lembar berita acara dan 43.7 detik untuk pengisian lembar daftar hadir.

\section{A. Kesimpulan}

\section{KESIMPULAN DAN SARAN}

Sistem informasi dokumen pendukung ujian akhir semester mampu melakukan proses pembuatan sekaligus mengisikan data-data pada lembar jadwal, lembar berita acara serta lembar daftar hadir secara terintegrasi dan otomatis.

Uji perbandingan waktu pengisian menunjukkan bahwa pengisian lembar dokumen yang dihasilkan oleh sistem membutuhkan waktu lebih cepat dengan selisih rata-rata waktu pengisian sebesar 97.85 detik untuk lembar berita acara ujian dan 43.7 detik lembar daftar hadir peserta ujian

\section{B. Saran}

Sistem ini dapat dikembangkan dengan cara memperbanyak fitur untuk pembuatan dokumen-dokumen pendukung ujian akhir semester yang belum tercakup dalam penelitian ini.

Sistem ini juga dapat diitegrasikan dengan sistem informasi akademik, sehingga menjadi sub-sistem yang khusus menangani penyiapan dokumen pendukung ujian akhir semester.

\section{UCAPAN TERIMA KASIH}

Terima kasih disampaikan kepada Ristekdikti atas pendanaan penelitian melalui hibah Penelitian Dosen Pemula berdasarkan surat keputusan Nomor 7/E/KPT/2019 tanggal 19 Februari 2019 dengan kontrak Nomor 113/SP2H/LT/DRPM/2019 tanggal 11 Maret 2019, Nomor 042/SP2H/LT/MONO/L7/2019 tanggal 26 Maret 2019, Nomor 0448.01/UNP-Kd/IV/2019 tanggal 1 April 2019.

\section{DAFTAR PUSTAKA}

[1] A. Luthfiarta, J. Zeniarja and A. Salam, “Algoritma Latent Semantic Analysis (LSA) Pada Peringkas Dokumen Otomatis Untuk Proses Clustering Dokumen”, Seminar Nasional Teknologi Informasi \& Komunikasi Terapan, hal 13-18, Semarang 2013.

[2] B.A. Hadfield, R.W. Glover, S.J. Coates and S. Hopkins, "Method and System for Document Collaboration". Amerika Serikat. US7496841B2, 2009

[3] Handika, I P. S., dan Suryawan, I G. T., "Sistem Informasi Pengarsipan Dokumen Berbasis Web”, JTIIK, Vol. 4, No. 3, 2017

[4] A. Simangunsong, "Rancang Bangun Document Management System Untuk Mengelola Dokumen Standart Operational Procedure", Jurnal Mantik Penusa, Vol. 2. No. 1, 2018.

[5] Tukino, "Perancangan Sistem Informasi Menajemen Proyek Pengaksesan Dokumen Perakitan PCBA di PT Surya Teknologi Batam Berbasis Web", TEKNOSI, Vol.02, No.03, 2016,

[6] Y. Fitriani dan R.Pekpahan, "Aplikasi Sistem Informasi Pengelolaan Arsip Pada Unit Pelayanan Pajak dan Retribusi Daerah Palmerah Jakarta”, PARADIGMA, Vol.XX, No.2, 2016.

[7] A. Kadir, "Tuntunan Praktis: Belajar Database Menggunakan MySQL",Indonesia, Yogyakarta, 2008.

[8] T. Sutabri, "Analisis Sistem Informasi, Indonesia”, Yogyakarta, 2012.

[9] Jogiyanto, “Analisis dan Desain Sistem Informasi”, Indonesia, Yogyakarta, 2005. 